Correction

\title{
Correction: Formation Mechanism of Trailing Oil in Product Oil Pipeline. Processes 2019, 7, 7
}

Enbin Liu* ${ }^{\mathbb{D}}$, Wensheng Li, Hongjun Cai and Shanbi Peng

Petroleum Engineering School, Southwest Petroleum University, Chengdu 610500, China; 201721000517@stu.swpu.edu.cn (W.L.); hoganchoi@163.com (H.C.); shanbipeng@swpu.edu.cn (S.P.)

* Correspondence: enbin.liu@swpu.edu.cn; Tel.: +86-139-8206-9645

Received: 1 June 2020; Accepted: 28 June 2020; Published: 13 July 2020

check for updates

We were not aware of some errors made in the proofreading phase; therefore, we wish to make the following corrections to the mathematical equations in the text in [1].

(1)

Figure 14 shows that the volume fraction of gasoline at $6 \mathrm{~s}$ to $9 \mathrm{~s}$ was less than $1 \%$. The distance between the two interfaces with $99 \%$ and $1 \%$ forward batch concentration is defined as the length of the contamination. Equation (9) can be modified to yield

$$
C=9[0.21 \ln (N)+0.96] V
$$

(2)

When the Reynolds number was larger than the critical Reynolds number of contamination, the formula for calculating the contamination length is

$$
C=11.75 d^{0.5} L^{0.5} \operatorname{Re}^{-0.1}+9[0.21 \ln (N)+0.96] V
$$

\section{References}

1. Liu, E.; Li, W.; Cai, H.; Peng, S. Formation mechanism of trailing oil in product oil pipeline. Processes 2019, 7, 7. [CrossRef]

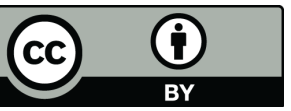

(C) 2020 by the authors. Licensee MDPI, Basel, Switzerland. This article is an open access article distributed under the terms and conditions of the Creative Commons Attribution (CC BY) license (http://creativecommons.org/licenses/by/4.0/). 